\title{
Pregnancy in pulmonary arterial hypertension associated with congenital heart disease: an illustrative case study
}

\author{
Robin Condliffe
}

\begin{abstract}
Background: Pregnancy in patients with pulmonary arterial hypertension associated with congenital heart disease is associated with a high risk of maternal mortality.

Case presentation: An illustrative case study based on experience gained from management of patients through pregnancy is discussed. A 22-year-old female with a history of a closed patent ductus arteriosus in childhood had been diagnosed with significant pulmonary arterial hypertension at the age of 19. Her clinical condition had improved following the commencement of oral combination therapy with sildenafil $25 \mathrm{mg}$ three times daily and macitentan 10 mg once daily. How should she be counselled regarding the risks of pregnancy and what are the most appropriate forms of contraception? What should the approach be if, despite adequate counselling, she subsequently becomes pregnant? Data to help guide decision-making are reviewed and a clinical approach is suggested.

Conclusions: Patients with pulmonary arterial hypertension should be advised against pregnancy and be given good contraceptive advice. If a patient with pulmonary arterial hypertension becomes pregnant and, after being fully counselled, chooses to proceed with their pregnancy, then they should be managed by an experienced multidisciplinary team.
\end{abstract}

Keywords: Pregnancy, Pulmonary arterial hypertension, Congenital heart disease, Contraception

\section{Background}

Pregnancy in patients with pulmonary arterial hypertension (PAH) associated with congenital heart disease (CHD) is associated with a high risk of maternal mortality. Current guidelines therefore strongly advise against pregnancy in this patient group. In this illustrative case study, based on experience gained from management of patients through pregnancy, data regarding risks of maternal mortality in patients with $\mathrm{PAH}$ are reviewed and approaches to contraception and to pregnancy are discussed.

Correspondence: robin.condliffe@sth.nhs.uk

Pulmonary Vascular Disease Unit, Royal Hallamshire Hospital, Sheffield S10 $2 J \mathrm{~F}, \mathrm{UK}$

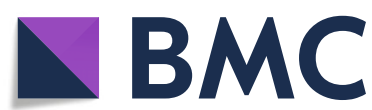

\section{Case presentation}

A 22-year-old female with a history of a closed patent ductus arteriosus in childhood had been diagnosed with significant PAH at the age of 19 . Her clinical condition had improved following the commencement of oral combination therapy with sildenafil $25 \mathrm{mg}$ three times daily and macitentan $10 \mathrm{mg}$ once daily. She was currently in World Health Organisation functional class II. Her incremental shuttle walking test distance was $380 \mathrm{~m}$. Nterminal pro B-type natriuretic peptide was modestly elevated at $485 \mathrm{pg} / \mathrm{mL}$. Echocardiography demonstrated a mildly dilated right ventricle with moderate hypertrophy and mildly reduced systolic function and mild right atrial dilatation. Left sided chambers were of normal size and left ventricular systolic function was preserved. There was no pericardial effusion. Systolic pulmonary arterial pressure was estimated at echocardiography to be $61 \mathrm{mmHg}$

(c) The Author(s). 2020 Open Access This article is licensed under a Creative Commons Attribution 4.0 International License, which permits use, sharing, adaptation, distribution and reproduction in any medium or format, as long as you give appropriate credit to the original author(s) and the source, provide a link to the Creative Commons licence, and indicate if changes were made. The images or other third party material in this article are included in the article's Creative Commons licence, unless indicated otherwise in a credit line to the material. If material is not included in the article's Creative Commons licence and your intended use is not permitted by statutory regulation or exceeds the permitted use, you will need to obtain permission directly from the copyright holder. To view a copy of this licence, visit http://creativecommons.org/licenses/by/4.0/ The Creative Commons Public Domain Dedication waiver (http://creativecommons.org/publicdomain/zero/1.0/) applies to the data made available in this article, unless otherwise stated in a credit line to the data. 
plus right atrial pressure. She therefore had low and intermediate risk factors according to the European Society of Cardiology/European Respiratory Society approach [1]. On examination she had no evidence of peripheral oedema and her jugular venous pressure was not elevated. She had a loud second heart sound and a moderate systolic murmur at the left lower sternal edge. How should she be counselled regarding the risks of pregnancy and what are the most appropriate forms of contraception? What should the approach be if, despite adequate counselling, she subsequently becomes pregnant?

\section{Discussion}

How should she be counselled regarding the risks of pregnancy and what are the most appropriate forms of contraception?

Cardiac output increases by approximately $50 \%$ during the first 20 weeks of pregnancy in health, while systemic vascular resistance falls significantly [2]. In patients with $\mathrm{PAH}$, the ability to increase cardiac output may be significantly limited. Historical reviews of maternal outcomes in PAH reported maternal mortality of $38-52 \%[3,4]$. A subsequent systematic review reported a maternal mortality of 25\% in PAH patients managed between 1997 and 2007 [5], while case series of patients managed mainly during the last decade observed mortality rates of 10-20\% [6-9]. Outcomes in 18 pregnant patients with Eisenmenger syndrome who proceeded to delivery have recently been published [10]. Maternal mortality was $6 \%$, while severe heart failure occurred in 4 patients, 3 patients received inotropic support, and 1 patient underwent extracorporeal membrane oxygenation (ECMO). In view of these data, international pulmonary hypertension and cardiovascular disease guidelines advise against pregnancy $[1,11]$.
It is therefore imperative that the risks of pregnancy and the recommended forms of contraception are discussed with patients with $\mathrm{PAH}$ associated with $\mathrm{CHD}$ at the time of diagnosis and that written advice is provided. Due to concerns regarding the pro-thrombotic effects of oestrogencontaining methods, the most commonly recommended methods are the desogestrel pill (e.g. Cerazette ${ }^{\text {Tu }}$ or Cerelle $\left.^{\mathrm{Tm}}\right)$, etonogestrel implant (e.g. Nexplanon $\left.{ }^{\mathrm{Tm}}\right)$ or intrauterine device (e.g. Mirena ${ }^{\text {tu }}$ ) (Table 1). Due to the risk of syncope during insertion, the intrauterine device should be inserted in the hospital setting. Bosentan is an inducer of cytochrome P-450 and hence the efficacy of cerazette and nexplanon may be reduced [13]; additional contraceptive methods are, therefore, required.

\section{What should the approach be if, despite adequate counselling, she subsequently becomes pregnant?}

Despite being counselled regarding the risks of pregnancy, some patients with PAH may actively choose to conceive or choose to proceed should they become pregnant. Other patients may present with PAH during pregnancy. For all pregnant patients the risks of proceeding versus termination should be discussed. If a patient decides to proceed, then a multidisciplinary approach to supporting pregnancy is required, involving experienced healthcare professionals (PAH/adult CHD physicians and nurses, obstetricians, midwives, anaesthetists, intensivists and neonatologists) [6]. Figure 1 summarises an approach to the management of a $\mathrm{PAH}$ patient who chooses to proceed with pregnancy. Endothelin receptor antagonists are potentially teratogenic and should, therefore, be stopped before conception or at the very early stages of pregnancy [14]. Several case reports and case series support the safety of sildenafil in pregnant $\mathrm{PAH}$ patients, with no reports of adverse effects on the

Table 1 Contraception in pulmonary arterial hypertension

\begin{tabular}{|c|c|c|c|}
\hline Method & $\begin{array}{l}\text { 1-yr failure rate: } \\
\text { typical use }(\%)\end{array}$ & $\begin{array}{l}\text { 1-yr failure rate: } \\
\text { perfect use }(\%)\end{array}$ & Comments \\
\hline Male condom & 15 & 2 & Efficacy is not high enough in typical use to use as sole method \\
\hline Combined oral contraceptive pill & 8 & 0.1 & Not recommended due to increased thrombotic risk \\
\hline Desogetsrel (e.g. Cerazette ${ }^{\mathrm{TM}}$ ) & 8 & 0.1 & $\begin{array}{l}\text { Efficacy is reduced in patients receiving bosentan and an } \\
\text { additional method is therefore required (e.g. barrier) }\end{array}$ \\
\hline $\begin{array}{l}\text { Medroxyprogesterone acetate } \\
\text { injection (e.g. Depo-Provera }{ }^{\mathrm{TM}} \text { ) }\end{array}$ & 3 & 0.3 & $\begin{array}{l}\text { Increased risk of thrombus compared with other non-oestrogen } \\
\text { hormonal methods }\end{array}$ \\
\hline $\begin{array}{l}\text { Etonogestrel implant (e.g. } \\
\text { Nexplanon }{ }^{\mathrm{TM}} \text { ) }\end{array}$ & 0.05 & 0.05 & $\begin{array}{l}\text { Efficacy is reduced in patients receiving bosentan and an } \\
\text { additional method is therefore required (e.g. barrier) }\end{array}$ \\
\hline Copper coil & 0.8 & 0.6 & \\
\hline Levonorgestrel coil (e.g. Mirena'TM) & 0.1 & 0.1 & $\begin{array}{l}\text { Requires placement in hospital due to the risk of vaso-vagal } \\
\text { events. }\end{array}$ \\
\hline Male sterilisation & 0.2 & 0.1 & \\
\hline Female sterilisation & 0.5 & 0.5 & Requires laparotomy (ligation) or hysteroscopy (Essure) \\
\hline
\end{tabular}

Adapted from Condliffe et al [12].

Reproduced from Condliffe R, Clift P, Dimopoulos K, Tulloh RMR. Management dilemmas in pulmonary arterial hypertension associated with congenital heart disease. Pulmonary Circulation 8(3), pp. 1-12. Copyright $\odot 2018$ by the Authors. Reprinted by permission of SAGE Publications, Ltd. 


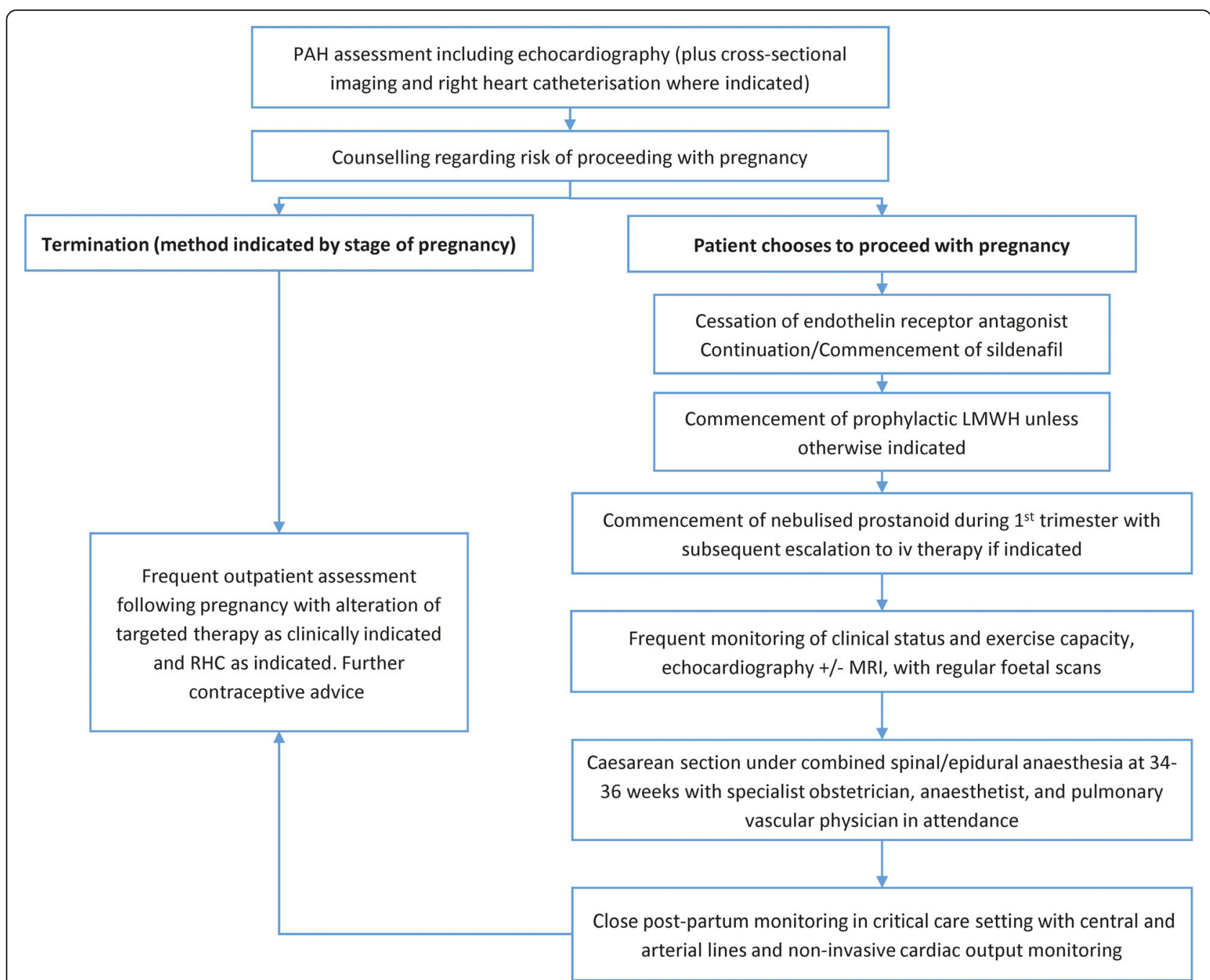

Fig. 1 Typical management of a patient with PAH who chooses to proceed with pregnancy. Adapted from Kiely et al [6]. Abbreviations: LMWH, low molecular weight heparin; MRI, magnetic resonance imaging; RHC, right heart catheterisation. Reproduced from Kiely D, Condliffe R, Webster V, Mills G, Wrench I, Gandhi S, Selby K, Armstrong I, Martin L, Howarth E, Bu'Lock F, Stewart P, Elliot C. Improved survival in pregnancy and pulmonary hypertension using a multiprofessional approach. BJOG 2010; 117:565-574 (DOI: https://doi.org/10.1111/j.1471-0528.2009.02492.x) with permission from BJOG

foetus $[7-9,15,16]$. Prostanoid therapy may also often be required via either the nebulised or intravenous route [6, $17,18]$; in our centre we routinely add in nebulised iloprost to sildenafil during the first trimester. Unless full-dose anticoagulation is indicated, we routinely commence patients on prophylactic low molecular weight heparin.

Patients should be carefully monitored throughout pregnancy, with regular assessments including exercise capacity and echocardiography or cardiac magnetic resonance imaging. Significant deterioration occurring during the first trimester suggests an inability to increase cardiac output sufficiently and should stimulate further discussions regarding termination. If termination is not performed, or if worsening of right ventricular (RV) function occurs later in pregnancy, then we would recommend switching from nebulised to intravenous prostanoid. The aim should be to deliver early at around 34-36 weeks' gestation although this may be brought forward if there are concerns regarding worsening RV function or impaired foetal growth. Although there is debate regarding the optimal method of delivery, many experienced centres deliver via elective Caesarean section under regional anaesthesia [19]. Indeed, in their systematic review, Bedard et al. found general anaesthesia to be associated with a four-fold increased risk of death as compared with regional anaesthesia, although patients receiving general anaesthesia were those with more severe disease [5].

Patients require close haemodynamic monitoring during the peri-partum period. Measurement of central venous pressure and saturation via a central line, systemic 
blood pressure via an arterial line and non-invasive cardiac output monitoring enable manipulation of RV preload (with fluid boluses or diuretics), RV afterload (with parenteral prostanoid), systemic vascular resistance (with pressor agents) and cardiac contractility (with inotropes) [14]. Certain agents often used during delivery may increase pulmonary vascular resistance (PVR); nitric oxide should be avoided, whilst oxytocin should be used with caution as a low dose infusion [6]. After delivery, significant fluid shifts into the systemic vasculature occur, which may be poorly tolerated in patients with pulmonary hypertension. The postpartum period is therefore a period of increased risk of mortality and close monitoring in the critical care setting for at least $72 \mathrm{~h}$ is advised [14].

\section{Outcome}

Despite full counselling, the patient became pregnant. The risks of proceeding with pregnancy were re-discussed and termination was offered. The patient, however, chose to proceed with the pregnancy. Macitentan was stopped during pregnancy and she was commenced on nebulised iloprost in addition to sildenafil. She was commenced on prophylactic-dose low molecular weight heparin, which was continued for 6 weeks following delivery. She was followed regularly during pregnancy, and her clinical state and echocardiographic parameters remained stable. Elective Caesarean section was performed under combined spinal-epidural anaesthesia at 36 weeks' gestation. Low-dose intravenous iloprost was commenced $48 \mathrm{~h}$ prior to delivery and continued for $72 \mathrm{~h}$ post-partum. She had an uneventful peripartum period. Following discussion regarding future contraceptive wishes, a Levonorgestrel coil was inserted following delivery. Macitentan was restarted and she was weaned off nebulised iloprost by 3 months post-partum.

\section{Conclusion}

Although outcomes in patients with PAH may have improved over recent years, pregnancy is still associated with a high risk of maternal mortality. Patients with $\mathrm{PAH}$ should therefore be advised against pregnancy and be given good contraceptive advice. If a patient with $\mathrm{PAH}$ becomes pregnant and, after being fully counselled, chooses to proceed with their pregnancy, then they should be managed by an experienced multidisciplinary team.

\section{Abbreviations}

ECMO: Extracorporeal membrane oxygenation; PAH: Pulmonary arterial hypertension; PVR: Pulmonary vascular resistance; RV: Right ventricular

\footnotetext{
Acknowledgements

The input of all members of the obstetric, anaesthetic, medical and intensive care team members into the management of patients in our unit is gratefully acknowledged.

\section{About this supplement}

This article has been published as part of Journal of Congenital Cardiology Volume 4 Supplement 1 2020: Unmet needs in Pulmonary Hypertension
}

associated with Adult Congenital Heart Disease (ACHD-PH). The full contents of the supplement are available at https://jcongenitalcardiology. biomedcentral.com/articles/supplements/volume-4-supplement-1

\section{Author's contributions}

The author was fully responsible for the design and writing of this article. The author(s) read and approved the final manuscript.

\section{Funding}

Medical writing support was provided by nspm Itd, Meggen, Switzerland. The manuscript was funded by a Medical and Educational Goods and Services (MEGS) grant and Actelion Pharmaceuticals UK Limited (who had no influence on manuscript writing).

\section{Availability of data and materials \\ Not applicable.}

Ethics approval and consent to participate

No ethics approval was required.

\section{Consent for publication}

The case history was altered in order to protect patients' identities.

\section{Competing interests}

$\mathrm{RC}$ has received honoraria for lecturing and advisory boards from Actelion, Bayer, GSK and MSD.

Received: 12 November 2020 Accepted: 12 November 2020 Published: 16 December 2020

\section{References}

1. Galie N, Humbert M, Vachiery JL, Gibbs S, Lang I, Torbicki A, et al. 2015 ESC/ ERS guidelines for the diagnosis and treatment of pulmonary hypertension: the joint task force for the diagnosis and treatment of pulmonary hypertension of the European Society of Cardiology (ESC) and the European Respiratory Society (ERS): endorsed by: Association for European Paediatric and Congenital Cardiology (AEPC), International Society for Heart and Lung Transplantation (ISHLT). Eur Heart J. 2016;37(1):67-119.

2. Robson SC, Hunter S, Boys RJ, Dunlop W. Serial study of factors influencing changes in cardiac output during human pregnancy. Am J Phys. 1989;256(4 Pt 2):H1060-5.

3. Gleicher $\mathrm{N}$, Midwall J, Hochberger D, Jaffin $\mathrm{H}$. Eisenmenger's syndrome and pregnancy. Obstet Gynecol Surv. 1979;34(10):721-41.

4. Weiss BM, von Segesser LK, Alon E, Seifert B, Turina MI. Outcome of cardiovascular surgery and pregnancy: a systematic review of the period 1984-1996. Am J Obstet Gynecol. 1998;179(6 Pt 1):1643-53.

5. Bedard E, Dimopoulos K, Gatzoulis MA. Has there been any progress made on pregnancy outcomes among women with pulmonary arterial hypertension? Eur Heart J. 2009:30(3):256-65.

6. Kiely DG, Condliffe R, Webster V, Mills GH, Wrench I, Gandhi SV, et al. Improved survival in pregnancy and pulmonary hypertension using a multiprofessional approach. BJOG. 2010;117(5):565-74.

7. Curry RA, Fletcher C, Gelson E, Gatzoulis MA, Woolnough M, Richards N, et al. Pulmonary hypertension and pregnancy--a review of 12 pregnancies in nine women. BJOG. 2012;119(6):752-61.

8. Jais X, Olsson KM, Barbera JA, Blanco I, Torbicki A, Peacock A, et al. Pregnancy outcomes in pulmonary arterial hypertension in the modern management era. Eur Respir J. 2012:40(4):881-5.

9. Duarte AG, Thomas S, Safdar Z, Torres F, Pacheco LD, Feldman J, et al. Management of pulmonary arterial hypertension during pregnancy: a retrospective, multicenter experience. Chest. 2013;143(5):1330-6.

10. Ladouceur M, Benoit L, Radojevic J, Basquin A, Dauphin C, Hascoet S, et al. Pregnancy outcomes in patients with pulmonary arterial hypertension associated with congenital heart disease. Heart. 2017;103(4):287-92.

11. Regitz-Zagrosek V, Roos-Hesselink JW, Bauersachs J, Blomstrom-Lundqvist C Cifkova R, De Bonis M, et al. 2018 ESC guidelines for the management of cardiovascular diseases during pregnancy. Eur Heart J. 2018;39(34):3165-241.

12. Condliffe R, Clift P, Dimopoulos K, Tulloh RMR. Management dilemmas in pulmonary arterial hypertension associated with congenital heart disease. Pulm Circ. 2018;8(3):2045894018792501. 
13. Venitz J, Zack J, Gillies H, Allard M, Regnault J, Dufton C. Clinical pharmacokinetics and drug-drug interactions of endothelin receptor antagonists in pulmonary arterial hypertension. J Clin Pharmacol. 2012;52(12):1784-805.

14. Hemnes AR, Kiely DG, Cockrill BA, Safdar Z, Wilson VJ, Al Hazmi M, et al. Statement on pregnancy in pulmonary hypertension from the pulmonary vascular research institute. Pulm Circ. 2015;5(3):435-65.

15. Goland S, Tsai F, Habib M, Janmohamed M, Goodwin TM, Elkayam U. Favorable outcome of pregnancy with an elective use of epoprostenol and sildenafil in women with severe pulmonary hypertension. Cardiology. 2010;115(3):205-8.

16. Tacoy G, Ekim NN, Cengel A. Dramatic response of a patient with pregnancy induced idiopathic pulmonary arterial hypertension to sildenafil treatment. J Obstet Gynaecol Res. 2010;36(2):414-7.

17. Elliot CA, Stewart P, Webster VJ, Mills GH, Hutchinson SP, Howarth ES, et al. The use of iloprost in early pregnancy in patients with pulmonary arterial hypertension. Eur Respir J. 2005;26(1):168-73.

18. Bildirici I, Shumway JB. Intravenous and inhaled epoprostenol for primary pulmonary hypertension during pregnancy and delivery. Obstet Gynecol. 2004;103(5 Pt 2):1102-5.

19. Duggan AB, Katz SG. Combined spinal and epidural anaesthesia for caesarean section in a parturient with severe primary pulmonary hypertension. Anaesth Intensive Care. 2003;31(5):565-9.

\section{Publisher's Note}

Springer Nature remains neutral with regard to jurisdictional claims in published maps and institutional affiliations.

Ready to submit your research? Choose BMC and benefit from:

- fast, convenient online submission

- thorough peer review by experienced researchers in your field

- rapid publication on acceptance

- support for research data, including large and complex data types

- gold Open Access which fosters wider collaboration and increased citations

- maximum visibility for your research: over $100 \mathrm{M}$ website views per year

At $\mathrm{BMC}$, research is always in progress.

Learn more biomedcentral.com/submissions 